\title{
A Rare Cause af Solid Mass in the Head and Neck Area and Kimura's Disease as a Diagnostic Dilemma
}

\author{
Baş ve Boyun Bölgesinde Nadir Bir Kitle Nedeni ve Tanısal \\ Karmaşa Olarak Kimura Hastalı̆̆ı
}

\author{
(D) Mustafa Şahin ${ }^{1}$, (D) Raşit Midilli², (D) Mine Hekimgi| \\ ${ }^{1}$ Adnan Menderes University Faculty of Medicine, Department of Otorhinolaryngology, Aydın, Turkey \\ ${ }^{2}$ Ege University Faculty of Medicine, Department of Otorhinolaryngology, İzmir, Turkey \\ ${ }^{3}$ Ege University Faculty of Medicine, Department of Pathology, Izmir, Turkey
}

Keywords

Kimura's disease, head and neck, neck mass

Anahtar Kelimeler

Kimura hastalığı, baş ve boyun, boyun kitlesi

Received/Geliş Tarihi : 21.04.2015

Accepted/Kabul Tarihi : 31.07.2015

doi:10.4274/meandros.2088

Address for Correspondence/Yazışma Adresi: Mustafa Şahin MD,

Adnan Menderes University Faculty of

Medicine, Department of Otorhinolaryngology, Aydın, Turkey

Phone : +90 5336545502

E-mail : mustafa.kbb@gmail.com

ORCID ID: orcid.org/0000-0002-9009-6389

(C) Meandros Medical and Dental Journal, Published by Galenos Publishing House.

This is article distributed under the terms of the Creative Commons Attribution NonCommercial 4.0

International Licence (CC BY-NC 4.0).

\begin{abstract}
Kimura's disease which is known as a self-limited chronic inflammatory disease with unknown etiology, that can be easily misdiagnosed, causing long standing tumorlike painless nodules in the subcutaneous tissue, localized especially in the head and neck region. It has usually good prognosis. Common characteristic features of Kimura's disease were peripheral eosinophilia and increased serum immunoglobulin E levels. Typical histological features of the lesions are prominent eosinophilic and lymphocytic infiltration and fibrosis. The aim of this case report was reminding the Kimura's disease, clinical features and treatment have been determined with the case reports, with the findings of a 43 years old woman and associated literature data.
\end{abstract}

Öz

Kimura hastalığı; tanısı oldukça zorlayıcı olabilen, deri altı dokuda uzun süreli, tümör benzeri ağrısız nodüllerle seyreden, özellikle baş-boyun bölgesinde yerleşen, iyi seyirli, kendini sınırlayan ve nedeni bilinmeyen kronik enflamatuvar bir hastalıktır. Laboratuvar bulgularında bu hastalığa spesifik bir özellik tanımlanmamıştır. Sıklıkla periferik kanda eozinofil artışı ve serumda artmış immünoglobulin $\mathrm{E}$ düzeyi birliktelik gösterir. Lezyonların tipik histolojik özellikleri belirgin eozinofilik ve lenfositik infiltrasyon, vasküler proliferasyon ve fibrozistir. Cerrahi eksizyon tanısal olabileceği gibi aynı zamanda tedavi edici de olabilmektedir. Bu makalede; şimdiye kadar klinik özellikleri ve tedavisi olgu sunumları ile belirlene gelmiş Kimura hastalığının, 43 yaşındaki bir kadın hastanın bulguları literatür bilgileri eşliğinde tartışılarak, tekrar hatırlatılması amaçlandı.

\section{Introduction}

Kimura disease (KD), which is one of the most difficult clinical entities concerning the diagnosis, is a rare, benign, chronic inflammatory disease with unknown etiology. It is most commonly reported in young-middle-aged men generally as palpable lymph nodes on head and neck region and mass lesions located commonly 
on large salivary glands, subcutaneous tissue and rarely on oral (1). There may be single or widespread lesions on the body; spontaneous remission may be seen, and the disease may also recur after months or years. In literature, it has many different names including, eosinophilic granuloma of lymph nodes and soft tissue, eosinophilic hyperplastic granuloma, angio-lymphoid hyperplasia (ESAH) with eosinophilia $(1,2)$. It was assumed to be developed as a result of self-limited autoimmune or allergic reactions triggered by an unknown agent (1). Although any specific laboratory finding was not defined, there may be eosinophilia on peripheral blood and tissues and an increase on serum immunoglobulin (Ig) E levels (2). In some previous reports; eosinophilia on peripheral blood or tissues, increase on serum IgE levels and soft tissue masses on head and neck region accompanied by recurrent lymphadenopathies for a long time has been defined as the characteristic triad of the disease $(2,3)$. Though many advanced investigations performed, this disease may not be diagnosed and the most important point for the diagnosis is the histopathological evaluation of tissue samples characterized by infiltration of lymphoid follicles by dense eosinophilic-lymphocytic inflammation, fibrosis and vascular proliferation (4). It may show spontaneous remission but may also recur after months and even after years. There is not a consensus about the treatment of this disease. Surgical excision is diagnostic and in some conditions, it may also be curative but ablative surgery should be avoided. In this disease that may show recurrences commonly, other treatment strategies include radiotherapy, systemic steroids, cyclosporine, pentoxifylline and some cytotoxic agents $(1,3)$.

\section{Case Report}

A 43-yr-old female patient was admitted with progressive, painless, widespread swellings on neck region for about 7 months. It was learnt that similar swellings also developed about 3 years ago from her history; but they could not be diagnosed though detailed laboratory examinations including complete blood count, peripheral blood smear, general biochemical panel, chest graph, serum viral serology, purified protein derivative (PPD) test, neck and abdominal ultrasounds and also fine needle aspiration biopsy (FNAB) obtained from one of the masses located on neck region were performed. At that time, except $1000 \mathrm{mg}$ amoxicillin-clavulanic acid combination she took at the very beginning of her symptoms for about 2 weeks, she did not take any other medical treatments and her symptoms resolved spontaneously. In her history, she reported appendectomy about 14 years ago and cholecystectomy 4 years ago without any known chronic illnesses or long-term medications. Complete head and neck physical examination including endoscopic investigations and systemic general physical examination were unremarkable except painless lymphadenopathies, determined on neck palpation at submandibulary region and on $2^{\text {nd }}$ level bilaterally with a maximum diameter of $2.5 \mathrm{~cm}$. They were having rubber consistency and covered with normal skin. Later, laboratory investigations were performed step by step including complete blood count, general biochemical panel, chest graph, serum viral serology, serological tests for toxoplasmosis and syphilis, PPD test, peripheral smear, thyroid function tests, rheumatologic serum markers such as antinuclear antibody, cytoplasmic antineutrophil cytoplasmic antibody, rheumatoid factor, sedimentation, serum IgG, A, M, E levels, neck and abdominal ultrasounds and computed tomography (CT) of neck region. In peripheral smear; on leucocyte formulation there were $16 \%$ of eosinophil and the absolute eosinophil count was determined as 1696 . Serum IgE level was $876 \mathrm{IU} / \mathrm{mL}$ (the upper limit was $100 \mathrm{IU} / \mathrm{mL}$ ). Neck ultrasound and CT revealed that there were many, diffuse, heterogeneous, and oval in shape, smooth bordered lymphadenopathies with a maximum diameter of $3 \mathrm{~cm}$ on submandibular, parotid and jugulodigastric regions bilaterally. Histological evaluation of FNAB material obtained from one of the masses located on neck region revealed benign cytology with ordinary lymphoid cell communities. Since a certain diagnosis could not be achieved with all those investigations, histopathological examination of 2 neighbor lymph nodes excised from the submandibular region was performed for both the diagnosis and exclusion of malignancy. In this evaluation, there were follicular lymphoid hyperplasia with obvious germinal centers, enlargement in paracortical space, post-capillary venule proliferation, eosinophil infiltration and eosinophilic micro-abscess foci with normal distribution of $T$ and $B$ lymphocytes in histochemical investigations with CD3 and CD20. On 
para-follicular region there were rarely CD30 positive active lymphoid cells, CD15 was negative, obvious capillary vessel network proliferation was determined with CD31 and CD34, evident increase in mast cells was determined with CD117 and mast cell tryptase, IgE positive plasma cells in germinal centers were defined and all those findings were compatible with the diagnosis of Kimura lymphadenopathy (Figure 1). Follicular hyperplasia with obvious germinal centers and eosinophilic infiltrate covered with fibrous tissue were determined (Figure 2). The patient was informed in detail after the diagnosis of KD, and she was advised the treatment methods recommended in literature including intralesional and systemic

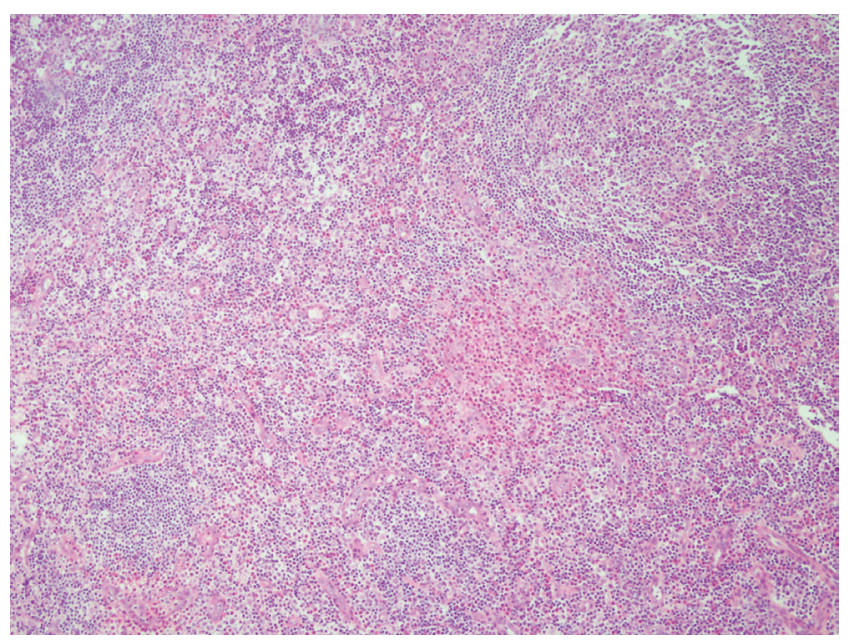

Figure 1a. In lymph node, obvious follicular hyperplasia and dense eosinophilic leucocyte infiltration on paracortex with postcapillary venule proliferation (hematoxylin and eosin, x10)

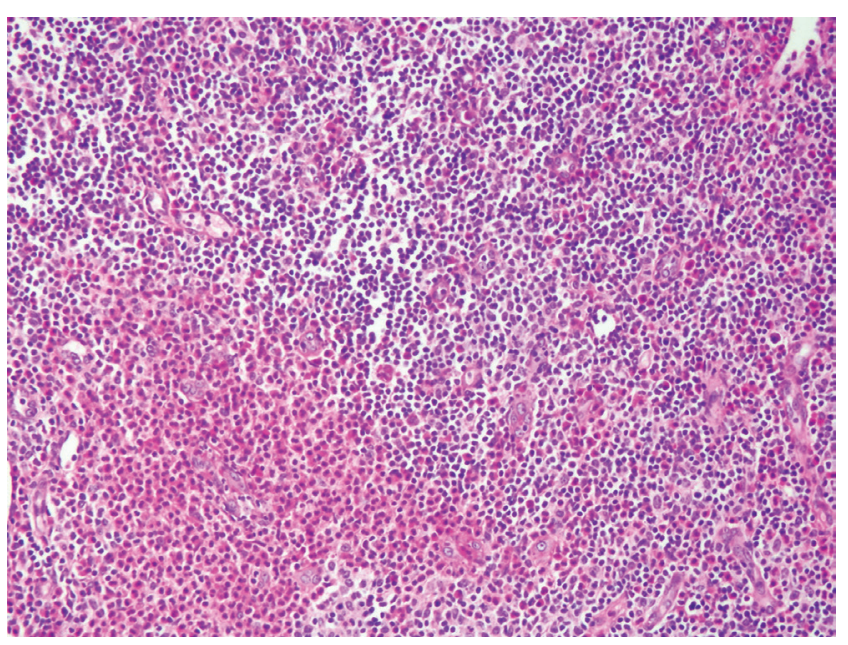

Figure 1b. Eosinophilic micro-abscess development on paracortex (hematoxylin and eosin, x20) steroid treatment, radiotherapy and treatment with some cytotoxic agents; surgical treatment was also explained but since the lesions were widespread on neck region surgical excision was not recommended as the first treatment method. The patient accepted the systemic steroid treatment that will be started with a dose of $1 \mathrm{mg} / \mathrm{kg}$, then will be reduced in 10 days and continued with 4 milligrams for 2 months as maintenance treatment; but she left the treatment voluntarily. About 15 months after the diagnosis, there was not any progression on her symptoms, physical examination or laboratory findings and there was a regression on diameters of lymph nodes located on neck. The patient was informed about the announcement of her data regarding the disease and treatment, and her verbal and written informed consents were obtained.

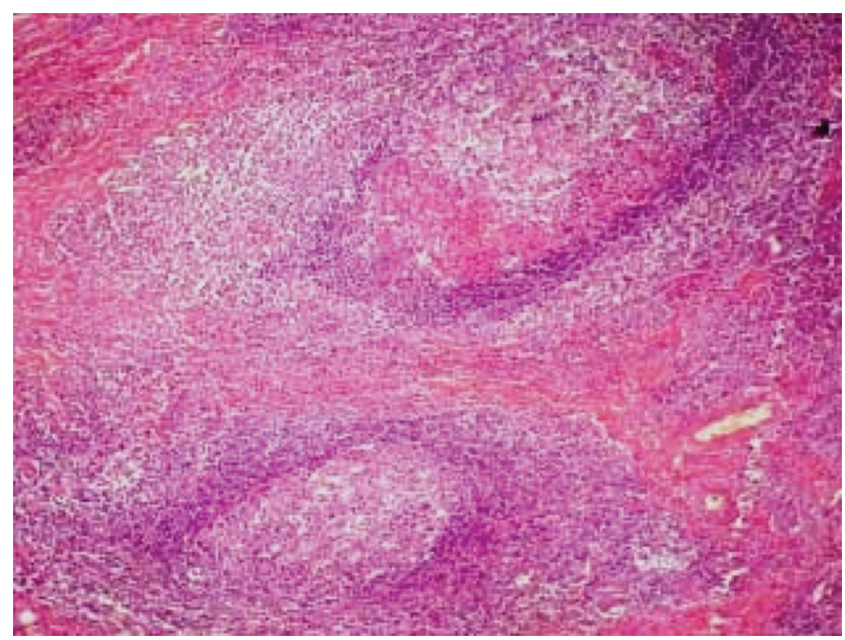

Figure 2. Interstitial fibrosis and lymphoid follicles with obvious germinal centers (hematoxylin and eosin, x10)

\section{Discussion}

This disease, which is first defined in China in 1937 by Kim and Szeto, took its place in literature with its today known name in 1948 after systematic investigations performed by Kimura et al. (5). In definition of this disease, based on its histopathological features, some terms such as eosinophilic granuloma, eosinophilic hyperplastic granuloma, angio-lymphoid hyperplasia with eosinophilia of lymph nodes and soft tissue were used and until 1994, totally 120 cases, most of which were from Asia, were reported in literature $(2,6)$. It is generally reported in middle-ages, with a male/female ratio of $4 / 1$ among diagnosed patients, and more 
commonly described in Asia. It is usually determined as painless tumor-like subcutaneous mass or regional lymphadenopathy on head and neck region. In some cases, local or widespread itching or subacute or chronic dermatitis associated symptoms, brick reddish papules on skin or subcutaneous nodules may accompany $(1,2)$. In a number of patients proteinuria due to nephrotic syndrome may be determined (7). In this reported case, there was not any complaint except swelling on neck and also there was not any finding on physical examination except widespread masses on neck. Although, in pathophysiology of the disease, allergic or autoimmune reactions triggered by an unknown agent have been suspected, in general its etiology is not identified and it is selflimited. Although not defined exactly, in disease development some theories such as corrupted T-cell immune-regulation or triggered IgE-mediated type 1 hypersensitivity reaction by Candida albicans, viruses, parasites or neoplasia resulting in increased secretion of eosinophil-trophic cytokines including interleukin 4-5-6 and eosinophilic cationic protein were proposed (1-4). In immunohistochemical investigations skin, lymph nodes and peripheral blood were determined to be rich in HLA-DR CD4 cells (4). In evaluation of disease activity, increase in eosinophilic cationic protein levels may be used. In $30-80 \%$ of patients with KD eosinophilia in peripheral blood, and increased serum IgE levels in some cases may be present (8). In our case report there were also peripheral eosinophilia and increased serum IgE levels present. In histopathological evaluations, lymphocytic infiltrations forming lymphoid follicles and within the follicles eosinophils, vascular proliferation, dense endothelial venules and fibrosis were observed $(1,4,9)$. Histopathological evaluation of our patient was concomitant with the features defined in literature and those features are the main diagnostic tool. Overlap of the disease symptoms with the symptoms of many other diseases, generally normal advanced and detailed laboratory investigations, absence of the definition of specific features of this disease, as mentioned previously absence of eosinophilia or IgE increase in tissue or blood in many patients, and lack of diagnosis even with the histopathological evaluations of tissue samples cause the diagnostic procedure of this disease to be very difficult putting the clinicians in a challenging situation in the face of the patient $(2,6,8)$. Before the diagnosis of $K D$, the patients are exposed to many laboratory tests for the differential diagnosis of mass lesions on neck region. Radiological investigations are insufficient for the diagnosis but may especially give data about the spread of the disease. Some specific features of KD were reported on $\mathrm{CT}$ and the magnetic resonance imaging (MRI) (10). In both imaging methods, the most common findings on head and neck region are enlarged salivary glands or increased salivary gland masses with enlarged lymph nodes. In KD, increased contrast enhancement in $\mathrm{CT}$ in affected lymph nodes and parotid gland, and elevated signal involvement may be observed in $\mathrm{T} 1$ and $\mathrm{T} 2$ weighted scans of MRI (11). The most valuable method in diagnosis is the histopathological evaluation of tissue and affected lymph node excisional biopsy material. Since it is almost impossible to make an exact diagnosis without biopsy, surgical procedures are required in many patients. FNAB of the mass is not diagnostic and for that reason surgical biopsy of the mass is mandatory $(2,6)$. Histopathological characteristic feature of KD is the presence of obvious germinal centers with dense IgE networks composed of cellular, vascular and fibrous components in affected lymph nodes, that was shown with immunoperoxidase studies. Cellular features of germinal center include dense eosinophilic infiltrations with eosinophilic microabscess, enclosing necrosis on centers and dense lymphocytes and plasma cells on background $(2-6,8)$. Similarly, in our case, the most important reasons for performing that much laboratory investigations for the diagnosis were; lack of determination of specific features of KD yet, generally lack of any symptoms of patients except swelling on neck, determination of laboratory investigations performed to the patients usually normal, lack of presence of elevated absolute eosinophilia count and/or serum IgE levels in many patients, and requirement of exclusion of many other disease in differential diagnosis. The main diseases that should be excluded are some malign diseases such as lymphoma, Kaposi's sarcoma, angiosarcoma, neck metastasis of malign tumors, dermatofibrosarcoma protuberance, cylindroma as well as some benign conditions such as hemangioma, pyogenic granuloma, Kikuchi disease, Mikulicz disease, angioimmunoblastic lymphadenopathy, ESAH and parasite diseases such as toxoplasmosis that may also cause 
increases in serum IgE levels and blood eosinophil counts $(2-4,8,11)$. KD may mimic many diseases such as Mikulicz disease, eosinophilic granuloma, lymphoma, salivary gland tumors and ESAH $(2,4)$. ESAH, that was previously regarded as the same disease with $K D$, in fact is the most commonly confused disease with KD. Dissimilar with KD, ESAH is a vascular tumor most commonly reported in women with advanced ages in Western Communities. Moreover, in ESAH lymphadenopathy is not common, there are many predominant, small erythematosus dermal papule or nodules present on head-neck region and peripheral eosinophilia (in general less than $10 \%$ ) is not common with normal serum IgE levels $(2,4,9)$. The diagnosis may be established on the basis of the biopsy with the clinical features, peripheral eosinophilia and elevated serum IgE levels in KD; however, despite all detailed methods, the disease may not be diagnosed. In ESAH, infiltration is more diffuse with less fibrosis, and germinal centers are not reported commonly but endothelial alterations are obvious in histological investigations $(4,9)$.

Up to date, any malign transformation of KD was not reported in literature. One of the many unknowns about the disease is the development of some renal diseases that may cause Nephrotic syndrome with a rate of $5-15 \%$ in KD (7). In $12-16 \%$ of patients, proteinuria may be determined. It is clearly known that, steroids are used as immunomodulator agents in treatment of both nephrotic syndrome and the KD (12). At that point, our patient was also followedup in nephrology department concomitantly, and renal involvement was not determined. Moreover, although involvement of major salivary glands and oral mucosa is also possible in KD, in our case major salivary glands or oral mucosa was not involved. We also investigated the lymph nodes, bone marrow, thorax, gastrointestinal system in detail, and did not determine any other accompanying pathology. Although the treatment after the diagnosis of the disease is still controversial, age and general health status of the patient as well as the spread and localization of the disease should be considered $(1,2)$. Diagnostic surgical excision for the isolated lesions may also be therapeutic at the same time; nevertheless, since autoimmune and hypersensitivity reactions are accused in pathophysiology, systemic or local intralesional steroid treatment is more commonly accepted. If the general condition of the patient does not let those treatments, or if the disease is highly widespread, another option is the radiotherapy $(6,11)$. It should be kept in mind that, this is a selflimited disease and malign transformation is not defined before. If the differential diagnosis from the possible malign lesions could be performed, as much as possible consideration of conservative treatments are advised $(1,3)$. For example, in critical lesions located near to some organs such as eyes, destructive treatment methods such as surgery or radiotherapy should be avoided. Unlike with those classical treatments, especially in patients with accompanying Nephrotic syndrome, some immune modulator agents such as trans-retinoic acid, cyclophosphamide, chewable nicotine tablets, vincristine, imatinib and leflunomide were practiced but adequate experience is not present about those treatments $(11,12)$. Although KD is a very well-known disease in pathology community since it has been discussed between the pathologists for long years, unfortunately, it is obvious that among ear, nose and throat physicians the data about this relatively rare disease is very limited and sufficient interest and awareness for KD is not present in that group. In conclusion, with this manuscript, we aimed to re-arouse the interest to the KD, the diagnosis of which may be very problematic for both the patients and the physicians, that may have many clinical pictures and by this way we emphasized the requirement for more certain algorithms in diagnosis and treatment of this disease with larger case series and reviews.

\section{Ethics}

Informed Consent: Patient was verbally informed about this scientific article and signed an informed consent form.

Peer-review: Externally and internally peerreviewed.

\section{Authorship Contributions}

Surgical and Medical Practices: R.M., M.Ş., Concept: R.M., M.Ş., M.H., Design: M.Ş., M.H., Data Collection or Processing: M.Ş., Analysis or Interpretation: M.Ş., R.M, M.H., Literature Search: M.Ş., R.M., M.H., Writing: M.Ş., R.M., M.H.

Conflict of Interest: No conflict of interest was declared by the authors.

Financial Disclosure: The authors declared that this study received no financial support. 


\section{References}

1. Biradar A, Patil AV, Kotennavar MS, Venkatachalaiah M. Kimura's Disease: A Case Report. Indian J Surg 2013;75(Suppl 1): 430-1.

2. Chen H, Thompton LD, Aguilena NS, Abbandanzo SL. Kimura's Disease: clinicopathological study of 21 cases. Am J Surg Pathol 2004; 28: 505-13.

3. Calli C, Oncel S, Pinar E, Bener S, Calli A. Kimura's disease: two case reports with a review of the literature. Turk J Ear Nose Throat 2004; 12: 139-43.

4. Kung IT, Gibson JB, Bannatyne PM. Kimura's disease: a clinico-pathological study of 21 cases and its distinction from angiolymphoid hyperplasia with eosinophilia. Pathology 1984; 16: 39-44.

5. Kimura T, Yoshisumura S, Ishikawa E. Unusual granulation combined with hyperplastic changes of lymphatic tissue. Trans Soc Pathol Jpn 1948; 37: 179-218.

6. Irish JC, Kain K, Keystone JS, Gullane PJ, Dardick I. Kimura's disease: An unusual cause of head and neck masses. J Otolaryngol 1994; 23: 88-91.
7. Gong Y, Gu JY, Labh S, Shi YL. Kimura disease accompanied with nephrotic syndrome in a 45-year-old male. Diagn Pathol 2015; 10: 43 .

8. Shetty AK, Beaty MW, McGuirt WF Jr, Woods CR, Givner LB. Kimura's Disease: a Diagnostic Challenge. Pediatrics 2002; 110: e39.

9. Muluk NB, Atasoy P, Koçak M. Baş-Boyun Bölgesinde Nadir Görülen İki Patoloji: Kimura Hastalığı ve Eozinofili ile Birlikte Giden Anjiolenfoid. KBB ve BBC Dergisi 2006; 14: 105-10.

10. Hobeika CM, Mohammed TL, Johnson GL, Hansen K. Kimura's disease: case report and review of the literature. J Thorac Imaging 2005; 20: 298-300.

11. Kurukahvecioğlu S, Yardımcı S, Kurukahvecioğlu O, Yılmaz E. Kimura's disease in the parotid and submandibular regions: two case reports. Kulak Burun Bogaz İtis Derg 2003; 11: 157-60.

12. Chartapisak W, Opastirakul S. Steroid-resistant nephrotic syndrome associated with Kimura's disease. Am J Nephrol 2002; 22: 381-4. 